\title{
U.S. Unemployment and Its Relation to Governmental Policies
}

\author{
Reza Fadaei \\ School of Business and Management, National University, USA
}

Copyright (C) 2015 by authors, all rights reserved. Authors agree that this article remains permanently open access under the terms of the Creative Commons Attribution License 4.0 International License

\begin{abstract}
The high rate of unemployment in the United States is the outcome of a series of problems with the current administration. In times of high unemployment and anemic economy, having the right governmental policies in place is critical to the future economic success of the United States. It is hypothesized that the current governmental policies have slow down the economic recovery and halt national job creation. This paper examines the actual governmental policies from an economic perspective, examining specifically at their effect on the economy, unemployment, and job growth in United States. It will demonstrate how these governmental policies have killed job growth and slow the rate of economic recovery following the latest recession. Finally it will offer alternative policies that would actually strengthen the economy and promote economic growth.
\end{abstract}

Keywords U.S. Unemployment, Government Policy

\section{Introduction}

The high rate of unemployment in the United States is the outcome of a series of problems innate to the current economy. As a consequence, a great deal of problems arise, leading many enterprises having to lay off qualified personnel because the expense of the wages paid to their laborers was just another cost that they couldn't afford.[3]. One may ask, why such a powerful country, have such a high rate of unemployment? The answer is complex. Unemployment is a result of an array of intricate factors such as unremarkable skill sets, advances in technology, job outsourcing, business competition with foreign countries, potential production output not being met, by U.S moving business operations to another country where labor cost is cheaper, and by population increase not sustained by the rise in goods productivity [5]. There is really not one set reason for why the economy has led to such a high rate of unemployment.

Regardless of the multiple reasons leading to unemployment, the high rate of unemployment in the United
States is related to the outcome of a series of problems linked to our current governmental administration. Current administration policies have slowed the economic recovery and killed job creation [3]. During the 2008 and 2012 presidential campaigns, president Obama promised that unemployment would not rise if the stimulus plan were passed, pledged to cut the deficit in half during in his first term, he promised to lift two million Americans from poverty, and he repeatedly touts that he is doing everything he can to support middle class Americans.[11]. However, according to a new survey from the associated press, nearly $80 \%$ of Americans are in near poverty. These population rely on welfare, or are unemployed amid signs of deteriorating economic security and an elusive American dream [5].

With the democrats holding the House, Senate, and Presidency for the first two years of the Obamas first term, it is appropriate to inquire as to why Obama's pledges have not been fulfilled? To explain such lack of compliancy, his administration is quick to blame its predecessor, or the Republican Party, for the administration's shortcoming, but for most of this administration, the Democrats have been able to pass any legislation they wanted. So why aren't their policies working? To the aforementioned question, James Pethokoukis notes in the New York Post, based on a Federal Reserve study conducted in 2014, looks at the behavior of recoveries from recessions across 59 advanced and emerging market economies during the last 40 years. His findings point at the federal found- to no great surprise- that recoveries tend to be faster after severe recessions, such as the one we just had. The deeper the downturn, the more robust the rebound; unless government messes things up [17]. Could it be that our actual governmental administration is promoting policies that are hindering strategies to help achieve these governmental promises? Corporate American thinks so!

\section{The Administration and Job Killing Policies}

This administration's progressive ideology and policies are killing American jobs and are slowing the rate of 
recovery of the recession of 2008. There are a number of key policies that are killing jobs and job creation in America, but the progressive ideology of the Obama administration blinds them to the facts and reality of the current situation in this country. For example, the governmental administration's foot-dragging on free trade agreements has killed job creation. The extended moratorium on oil drilling, followed by new regulations, has also killed job creation [13].

This administration refuses to build the Keystone XL pipeline, killed jobs. The ever expanding Environmental Protection Agency regulations, kill jobs. Extending unemployment insurance-part of the failed 'stimulus' was a humanitarian gesture, but it killed jobs. Even increasing deficit spending has a job-killing effect, the opposite of what Obama's administration espouses. Then there's Obamacare, which if it goes into full effect, will be one of the biggest job killers of modern times. [13]. Therefore, in order to truly understand how these failed policies have killed job creation or slowed the rate of economic recovery, it is important to dissect each policy as follows.

\section{Stimulus, Green Energy Policy Wrong or Right?}

In the first few weeks of the Obama's administration, congress passed a $\$ 787$ billion stimulus bill that was supposed to create jobs and "invest" in national infrastructure. During this period, Americans heard a lot about "shovel ready jobs," but not many were "shovel ready" and for the amount of money spent, there weren't that many jobs created [6]. Of all of these policies, the stimulus program had the most promise for helping lower unemployment, yet, it never came to fruition. In fact, it tended to frighten employers because they were uncertain how high taxes would increase in order to pay for the increased cost of the Stimulus Policy [8].The stimulus program, in addition to being unfocused, it used temporary government money to try to induce economic growth, instead of creating long-term sustained growth through the private sector; a policy that was doomed to fail from the onset, or at least, doomed to be only a short-term fix for a longer-term problem. Had that Stimulus money been infused into the private sector, it could have increased investment, and in return, increase job growth, unfortunately, this type of policy is the antithesis of progressive thought.

The next Progressive Policy that has slowed economic growth and killed jobs is the Green Energy Policy. It has been discovered that the data used by scientist to support the Global Warming thesis was manipulated and /or ignored in an attempt to support the Global Warming claim. None-the-less, this administration supports this bunk science and has spent/ wasted billions of dollars trying to reduce carbon emissions through alternative energy projects [6]. Therefore, job creation based on green energy projects has so far been very disappointing. According to a recent Wall Street Journal analysis, $\$ 4.3$ billion of public funding allocated to wind energy- under Section 1603 of the
American Recovery and Reinvestment Act- there were 36 wind farms that employed 7,200 American workers during the peak of their construction, or an average of 200 workers per project. [10]. According to these companies and state and local government economic development officials, those projects employed only about 300 workers, at a cost of taxpayers of more than $\$ 14$ million per permanent job [6]. That is a huge investment for very little return. In the meantime, the administration spends billions of dollars on failed Green Energy companies with very few permanent jobs to show for it.

In addition to promoting Green energy, the administration is trying to reduce the use of fossil fuels, even though energy production through fossil fuels is cheaper for the American consumer and business. Over the last several months, the plug was pulled on two state-of-the-art coal projects in Texas that were projected to exceed $\$ 5.5$ billion in private investment and create hundreds of jobs. What was the reason? The Obama administration's ongoing push for climate regulations that will effectively regulate coal, and thousands of coal jobs, leading them to out of existence [10].

Reducing the use of coal is another Administration policy tied to the bunk science of Global Warming. Energy is a cost driver for manufacturing and other industries. By reducing energy production through the use of coal, this governmental policy is driving up the costs to the consumer and businesses, which will either slow their growth or eliminate it all together as it is too costly to keep the lights on.

If the Obama's administration continues to implement these proven failed policies, inevitably, energy cost is going to continue to rise. Soon, not only will Americans be forced to stay in their homes because they cannot afford gas for their cars, but they will not be able to heat or cool their homes because the energy costs will be exorbitant. The coal policy is yet another policy killing jobs and stifling the present economy.

\section{Taxes}

The next policy of this administration that is killing jobs is the Liberal Tax and Spend policy.

The president's and congressional democrats insistence on higher net taxes is a job-killer in several ways: higher taxes prevent businesses from expanding and deter consumers from spending. Many in the middle class already feel that taxes are extortionate and, fearing even higher taxes, have decreased their spending. Thereby reducing demand for goods and services. [9].

As economists know, this reduction in demand for goods and services, slows the economy and kills job growth. In addition to high taxes, and environmental regulations, the Obama administration has attached financial reform as another burdensome overregulation of business. The financial reform legislation is itself a huge tax increase in the form of higher costs and reduced services in the financial sector. Those can't be expansionary. But, most of all is the prospect of tax increases on both capital and labor. We have 
tried raising marginal taxes in the middle of a deep recession and the outcome wasn't good. All bankers' bashing hasn't helped either [8].

When one adds all of the overregulation to the other policies of our actual governmental administration, the result is a reduction in the growth of the economy and fewer jobs.

\section{Result and Recommendations}

The U.S. Chamber of Commerce recommended six areas where the administration could help grow the economy and reduce unemployment. In their letter to the administration they suggested that the Obama's administration should: 1-create growth and jobs tax policy; 2- restore fiscal health; 3-expand trade and export-driven jobs; 4-rebuild and expand infrastructure; 5-ease regulatory burdens; 6-and eliminate uncertainty for business owner [14]. However, the Obama administration seems to be doing the opposite of all these suggestions.

Why hasn't this governmental administration recovery been better? The truth is that they have no one to blame but their own strict, uncompromising devotion to its academic progressive ideology [5].

\section{Conclusions}

In the previous nine recessions before this last one, it took an average of just 24 months to regain all the jobs lost. However, it will take about 80 months - almost seven years for the country to regain all the jobs lost in the last recession if we continue at this administration's crawling job creation pace [1]. The policies of this administration have killed job growth and slowed the rate of recovery. The very same policies that progressives claim are protecting or 'growing the middle class' are in effect doing the complete opposite-they are preventing normal to strong economic growth.

\section{REFERENCES}

[1] Amadeo, K. (2013). How Do Obama and Bush Compare on Their economic Policies? Retrieved from http://useconomy.about.Com/od/candidatesandtheeconomy/a /obama-Bush-Economy.

[2] Bader, H. (2012) Economic "Recovery" Is Slow and Weak Due to Obama Administration Policies. Retrieved from http://www.openmarket.org/2012/04/02

economic-recovery-is

slow-and-weak-due-to-Obama-administration-policies.

[3] Berrier, J. (2009). Gingerich's attack on the "Obama administration's job-killing policies" falls flat. Retrieved from

http://mediamatters.org/research/2009/11/13/gingrichs-attack -on-the-Obama-administrations-j/156971.
[4] Carson. B., Thomas, W. L., \& Hecht, J. (2005). Macroeconomic issues today: Alternative approaches. Armonk, NY: M.E. Sharp.

[5] Giokaris. J. (2013). Obama's Economic Policies Are Hurting the Middle Class More Than Anyone Else. Retrieved from http://www.policymic.com/articles/57181/obama-s-ecnomicpolices-are-hurting-the-middle-class-more-than-anyone-else.

[6] Hemphill, T. and Perry, M. (2012). How Obama's Energy Policy will kill jobs. Retrieved from http://www.american.com/archive/2012/march/how-obamasenergy-policy-will-kill-jobs.

[7] Kurtzleben, D. (2013). Obama Announces Two New Executive Orders to Create Jobs. Retrieved from http://www.usnews.com/news/articles/2013/05/09/obama-an nounces-two...Inding-on-manufacturing-can-spur -growth-and-shift-the-conversation.

[8] McTeer, B. (2010). Are the Obama Administration's Policies Making the recession Worse? Retrieved from http://economyblog.ncpa.org/are-the-obama-administrationspolicies-making-the recession-worse.

[9] Miller, H. (2011). No End in Sight to Obama's Job-Killing Policies. Retrieved from

http://www.forbes.com/sites/henrymiller/2011/09/06/no-endin-sight-to-obama-job-killing-policies.

[10] Obama Administration's "all-of-the-Above but Nothing-from-Below" Energy Policy Pushes State-of-the-Art Coal Projects Over the Edge. (2013). Retrieved from http://energycommerce.house.gov/brand/obama-administrati ons-all-above...ing-below-energy-policy-pushes-state-art-coa 1-projects-over-the-edge.

[11] Obama Administration's EPA Assault on American Jobs. (2010) Retrieved from http://www.gop.gov/policy-news/10/08/12/obama-aministrat ions-epa-assault-on.

[12] Obama Economic Policies Guarantee A Jobless Recover. (2013) Retrieved from http://news.investors.com/ibd-editorials/061313-659928-bla me-administration-for-lack-of-job-groth.htm

[13] Payne, A. (2012). Morning Bel: Has Any Administration Policy not killed jobs lately? Retrieved from http://blog. Heritage.org/2012/08/03/ morning-bell-has-any-administration-policy-not-killed-jobs-1 ately/.

[14] Pepitone, J. (2010). Business leaders: Obama policies 'jobdestroying.' Retrieved from http:// money.cnn.com/2010/07/ 14/news/ economy/ Obama-jobs/index.htm.

[15] Sowell, T. (2012). Obama's Unemployment problem. Retrieved from http://www.nationalreview.com/articles/332601/ Obama-sunemployment-problem-Thomas-Sowell.

[16] Tong, C., Tong, L., \& Tong, J. (2012). High Unemployment in the United States: Causes and Solutions.

[17] Zarroli, J. (2012). Did Obama's Policies Help, Or Hinder, and The Economy? Retrieved from http://www.nor.org/2012/04/17/150732473/did-obamas-poli cies-help-or-hinder-the-economy. 